\title{
Association between $p 53$ codon 72 polymorphism and systemic lupus erythematosus
}

\section{Zależność między polimorfizmem kodonu 72 genu p53 a toczniem rumieniowatym układowym}

\author{
Mohammad Nabavi ${ }^{1}$, Abbas Ghaderi², Mohammad Javad Fattahi², N. Danaie ${ }^{3}$, R. Zangooie ${ }^{4}$, \\ Mohammad Faranoush 5 \\ ${ }^{1}$ Department of Allergy and Clinical Immunology, Tehran University of Medical Sciences, Hazrat Rasool Akram Hospital, Tehran, Iran \\ ${ }^{2}$ Shiraz Institute for Cancer Research, Shiraz University of Medical Sciences, Shiraz, Iran \\ ${ }^{3}$ Semnan University of Medical Sciences, Semnan, Iran \\ ${ }^{4}$ MAHAK Hospital, Semnan, Iran \\ ${ }^{5}$ Iranian Blood Transfusion Organization (IBTO), Hazrat Rasool Akram Hospital, Iran University of Medical Sciences, Tehran, Iran
}

Key words: p53, systemic lupus erythematosus, polymorphism, disease activity.

Słowa kluczowe: p53, toczeń rumieniowaty układowy, polimorfizm, aktywność choroby.

\section{Sum mary}

Aim: Systemic lupus erythematosus (SLE) is a systemic vasculitic disorder, with multiple genes involved in the disease pathogenesis. The $p 53$ gene plays an important role in controlling the cell cycle. We aimed to study the prevalence of $p 53$ polymorphism in SLE patients and analyze the relationship between the $p 53$ polymorphism and clinical-laboratory features of the disease.

Material and methods: This case-control study was conducted on patients with confirmed SLE at Namazi Hospital, Shiraz, Iran. Seventy-seven patients with SLE including $9(11.8 \%)$ men and $68(88.2 \%)$ women with mean age of $25.61 \pm 10.69$ years and 80 healthy controls with mean age of $51.82 \pm 14.25$ years were included. The patients' information, including the epidemiological profile, disease history, disease symptoms and also the laboratory findings, were extracted from the hospital records. The $p 53$ expression was determined in lyzed lymphocytes. The data were analyzed using SPSS software version 14.00 for Windows considering $p<0.05$ as statistically significant.

Results: The frequencies of Arg/Arg, Pro/Pro and Arg/Pro among normal controls were $38.8 \%, 28.8 \%$ and $37.5 \%$, respectively, but in the patients, Arg/Arg, Pro/Pro and Arg/Pro genotypes frequencies were shown to be $29.2 \%, 12.3 \%$ and $58.5 \%$, respectively. Thus, heterozygous form of this polymorphism was shown to be associated with the disease more than the homozygous alleles. There was a significant relationship between the different allele types of p53 and some clinical features of SLE. There was no association between the different allele types and any
\end{abstract}

\section{Streszczenie}

Cel pracy: Toczeń rumieniowaty układowy (TRU) jest schorzeniem tkanki łącznej o przebiegu układowym. W patogenezie choroby uczestniczy kilka genów, spośród których gen p53 odgrywa istotną rolę w kontroli cyklu komórkowego. Celem badania była analiza częstości występowania polimorfizmu genu $p 53$ u pacjentów z TRU oraz zależności między polimorfizmem genu 553 a cechami klinicznymi i laboratoryjnymi choroby.

Materiat i metody: Badanie kliniczno-kontrolne przeprowadzono u pacjentów z rozpoznanym TRU w Szpitalu im. Namaziego w Sziraz (Iran). Do badania zakwalifikowano 77 pacjentów z rozpoznanym TRU - 9 mężczyzn (11,8\%) oraz 68 kobiet $(88,2 \%)$ o średniej wieku 25,61 $\pm 10,69$ roku, a także 80 osób zdrowych o średniej wieku $51,82 \pm 14,25$ roku, tworzących grupę kontrolną. Z kartoteki szpitalnej pozyskano dane uczestników badania, uwzględniając profil epidemiologiczny, wywiad chorobowy, objawy schorzenia oraz wyniki badań laboratoryjnych. Ekspresję genu p53 oznaczano w lizowanych limfocytach. Uzyskane dane analizowano przy wykorzystaniu oprogramowania SPSS w wersji 14.00 dla systemu Windows, przyjmując poziom istotności statystycznej jako $p<0,05$.

Wyniki: Częstość występowania genotypów Arg/Arg, Pro/Pro i Arg/ Pro wśród osób zdrowych z grupy kontrolnej wyniosły odpowiednio 38,8\%; 28,8\% i 37,5\%, natomiast w grupie pacjentów z TRU - odpowiednio $29,2 \% ; 12,3 \%$ i $58,5 \%$. Wykazano tym samym większą zależność między chorobą a postacią heterozygotyczną badanego polimorfizmu niż występowaniem alleli homozygotycznych. Stwierdzono istotną zależność między różnymi typami alleli genu

Address for correspondence:

Mohammad Faranoush, MD, Associate Professor, IBTO, P.O. Box: 13185-1678, Tehran, Iran, tel. +98-21-88601582, e-mail: swt_f@yahoo.com Submitted: 23.06.2013 
of the initial manifestations of the disease and the laboratory findings, as well.

Conclusions: In an Iranian population the functional oncoprotein of p53 with codon 72 polymorphism may play an important role in the pathogenesis and clinical presentation of SLE.

\section{Introduction}

Systemic lupus erythematosus (SLE) is a multisystem autoimmune disease characterized by acute and chronic inflammation of various tissues in various organs such as joints, heart, lung, kidneys, skin, etc, which leads to tissue damage $[1,2]$.

Various factors including genetic, epigenetic, ethnic, immunoregulatory, hormonal, and environmental factors have been associated with SLE [3-5]. It seems that interaction of specific genetic risk factors with various environmental factors causes abnormal immune responses $[2,6,7]$. However, the exact etiology of SLE has not yet been identified.

SLE is a multifactorial disease and in addition to the environmental factors multiple genes contribute to the development of the disease $[8,9]$. Although SLE inheritance does not follow Mendelian inheritance patterns, it has a strong genetic basis with heritability estimates of more than $66 \%$ [10]. Up to now, more than 30 genes have been identified that have been associated with SLE and contribute to the mechanisms of SLE and predispose individuals to SLE $[8,9]$. Well-known genetic risk factors that contribute to SLE development include genetic variants of HLA and Fc $\gamma$ receptor genes, IRF5, STAT4, PTPN22, TNFAIP3, BLK, BANK1, TNFSF4 and ITGA $[8,9]$. In polygenic inheritance, many genetic variants each with a small to moderate effect size contribute to SLE development.

Products of these genes associated with SLE contribute to key immunologic pathways such as Toll-like receptors, signaling pathways, immune regulation pathways and apoptosis $[8,9]$.

Genetic risk factors have not been totally identified. The $p 53$ is one of the candidate genetic risk factors. p53 controls cell cycle activities leading to apoptosis of autoreactive cells, preventing the proliferation and differentiation of these cells. As a result, any mutations in the p53 gene may cause cancer and autoimmune diseases [11].

The p53 suppressor gene has been located on the short arm of chromosome 17 in exon 11. DNA damage increases p53 expression which subsequently stops the cell cycle and repairs DNA or induces cell apoptosis [11-15].

Among 14 known polymorphisms of the p53 gene, codon 72 polymorphism is the most common polymorphism associated with cancer in the general population [16]. p53 a niektórymi cechami klinicznymi TRU. Nie potwierdzono natomiast związku między różnymi typami alleli a początkowymi objawami choroby ani wynikami badań laboratoryjnych.

Wniosek: W populacji irańskiej funkcjonalna onkoproteina p53 z polimorfizmem kodonu 72 może odgrywać ważną rolę w patogenezie i obrazie klinicznym TRU.

Many studies have evaluated $p 53$ polymorphism in which arginine to proline substitution at codon 72 changes the function of the p53 molecule and predisposes the individual to various diseases including cancer and autoimmune diseases [17-20]. As there is no such information about p53 polymorphism in Iranian patients with SLE, this study aimed to investigate the p53 polymorphism in SLE patients and evaluate the relationship between p53 and clinical and laboratory features of the disease.

\section{Material and methods}

In a case-control study, 77 patients (68 female and 9 male) with confirmed diagnosis of SLE who were admitted to Namazi Hospital, affiliated to Shiraz University of Medical Sciences, from 2003 to 2005, were included. Also, 80 healthy individuals who had been referred to the laboratory and gave a blood sample for other reasons were selected as controls.

The information required was extracted from the files and by visiting the patients. Informed consent was taken from the patients or their parents. The study protocol was approved by the ethics committee of the university.

Data including age, gender, onset of symptoms, first manifestation of the disease, complications related to the involvement of each organ and laboratory findings were collected. Then, the prevalence of the patients with homozygous or heterozygous polymorphism and the relationship between any of the mentioned parameters and the allele type were determined.

\section{Implemented methods}

By taking 10 cc of fresh blood, DNA was extracted using the salting-out method. The peripheral blood of the controls was obtained and DNA was extracted from them as well. PCR was performed to determine codon 72 polymorphism on the $p 53$ gene. One pair of primers was designed for each allele separately (Arg and Pro). The sequence of forward and reverse primer pairs was as follows:

- Arg F: TCC CCC TTG CCG TCC CAA,

- Arg R: CTG GTG CAG GGG CCA CCC,

- Pro F: GCCAGAGGCTGGTCCCCC,

- Pro R: CGTGCAAGTCACAGACTT. 
Table I. Frequency of p53 genotypes in SLE patients

\begin{tabular}{|lccccc|}
\hline \multirow{2}{*}{ Group } & & \multicolumn{5}{c|}{ p53 genotype } \\
\cline { 2 - 6 } & & AA & PP & AP & Total \\
\hline \multirow{2}{*}{ Control } & $n$ & 31 & 19 & 30 & 80 \\
\hline \multirow{nyyyyy}{*}{ SLE } & $\%$ & 38.8 & 23.8 & 37.5 & 100 \\
& $n^{*}$ & 22 & 11 & 32 & 65 \\
\hline Total & $\%$ & 28.6 & 14.3 & 41.6 & 100 \\
\hline & $n$ & 53 & 30 & 62 & 145 \\
\hline
\end{tabular}

${ }^{\star} D N A$ analysis was performed in 65 patients

PCR products were analyzed using $2 \%$ agarose gel electrophoresis, with ethidium bromide staining, and DNA detection was done with a UV transilluminator device.

PCR products were $141 \mathrm{bp}$ and $177 \mathrm{bp}$ for arginine and the proline containing alleles, respectively. For heterozygous samples, both PCR bands appeared while only one band of the spectrum appeared for homozygous samples.

\section{Data analysis}

The data were analyzed using SPSS software version 14.00 for Windows (SPSS Inc., Chicago, IL) and the Pearson $\chi^{2}$ test was used for data analysis. $P$ value $<0.05$ was considered as the statistically significant level.

\section{Results}

Among 77 patients studied with the mean age of $25.61 \pm 10.69$ years, $9(11.7 \%)$ patients were male and 68 (88.3\%) were female. The mean age at the onset of the first symptoms of the disease was $20.65 \pm 1.27$ years.

Table II. Initial clinical manifestations of SLE patients

\begin{tabular}{|lc|}
\hline Initial sign & Prevalence (\%) \\
\hline Fever & 37 \\
\hline Arthritis & 33.3 \\
\hline Arthralgia & 28.4 \\
\hline Malar rash & 22.2 \\
\hline Edema & 8.6 \\
\hline Skin & 7.4 \\
\hline Thrombosis & 7.4 \\
\hline Fatigue & 7.4 \\
\hline Seizure & 7.4 \\
\hline Anorexia & 4.9 \\
\hline Other & 33.9 \\
\hline
\end{tabular}

Mean age of the control group was $51.82 \pm 14.25$ years and all of them were female.

Of 77 patients successful DNA analysis was performed only in 65 patients. The frequency of p53 alleles in the patients with SLE was $41.6 \%$ for Arg/Pro, 28.6\% for Arg/Arg and $14.3 \%$ for Pro/Pro while in the control group the most frequent type of allele was Arg/Arg with $38.8 \%$; however, the frequency of Arg/Pro and Pro/Pro alleles was respectively $37.5 \%$ and $23.8 \%$. There was a significant difference in the frequency of alleles between the SLE and control groups ( $p=0.03$ ) (Table I).

About $71.9 \%$ of the patients had no family history of SLE while a positive family history of SLE was found in $20.9 \%$ of the patients; positive family history of other rheumatic diseases and cancer in first-degree relatives was seen in $7 \%$ and $4.7 \%$ of the patients, respectively.

Regarding the frequency, the most important initial signs and symptoms were fever in 37\%, arthritis in 33\%, arthralgia in $28.4 \%$ and malar rash in $22.2 \%$ of the patients (Table II).

Among the lupus criteria for diagnosis, the most common findings were renal involvement (82.7\%), anti-nuclear antibody (ANA) (81.5\%), hematologic manifestation (76.5\%), malar rash (74.1\%), arthritis (72.7\%), photosensitivity (48.1\%), immunologic findings (45.5\%), oral ulcer (38.3\%), neurologic manifestations (seizures and psychosis) (18.5\%), serositis (17.3\%) and discoid rash (14.8\%).

There was no significant correlation between the SLE initial manifestations, laboratory findings and different alleles of the $p 53$ gene $(p>0.05)$. However, there were significant relationships between diarrhea, pulmonary involvement, photosensitivity, malar rash and p53 gene polymorphism $(p<0.05)$ (Table III).

\section{Discussion}

According to the findings of the present study, there are significant associations between the different allele types of p53 codon 72 and SLE in our population. 
Table III. Relationship between clinical manifestations including diarrhea, pulmonary involvement, photosensitivity, malar rash and $p 53$ gene polymorphism

\begin{tabular}{|c|c|c|c|c|}
\hline \multirow{2}{*}{ Manifestation } & \multicolumn{3}{|c|}{ p53 genotype } & \multirow{2}{*}{$p$ value } \\
\hline & AA & AP & PP & \\
\hline $\begin{array}{c}\text { Diarrhea } \\
\text { yes, } n(\%) \\
\text { no, } n(\%)\end{array}$ & $\begin{array}{c}5(71.4) \\
12(22.2)\end{array}$ & $\begin{array}{c}0 \\
36(66.7)\end{array}$ & $\begin{array}{l}2(28.6) \\
6(11.1)\end{array}$ & $0.003^{*}$ \\
\hline $\begin{array}{c}\text { Pulmonary involvement } \\
\text { yes, } n(\%) \\
\text { no, } n(\%)\end{array}$ & $\begin{array}{l}11(42.3) \\
8(20.5)\end{array}$ & $\begin{array}{c}0 \\
23(59)\end{array}$ & $\begin{array}{l}15(57.7) \\
8(20.5)\end{array}$ & $0.020^{*}$ \\
\hline $\begin{array}{c}\text { Photosensitivity } \\
\text { yes, } n(\%) \\
\text { no, } n(\%)\end{array}$ & $\begin{array}{c}15(46.9) \\
4(12.1)\end{array}$ & $\begin{array}{l}15(46.9) \\
23(69.7)\end{array}$ & $\begin{array}{l}2(6.2) \\
6(18.2)\end{array}$ & $0.007^{\star}$ \\
\hline $\begin{array}{c}\text { Malar rash } \\
\text { yes, } n(\%) \\
\text { no, } n(\%)\end{array}$ & $\begin{array}{l}17(34) \\
2(13.3)\end{array}$ & $\begin{array}{c}25(50) \\
13(86.7)\end{array}$ & $\begin{array}{c}8(16) \\
0\end{array}$ & $0.034^{*}$ \\
\hline
\end{tabular}

${ }^{*} p<0.05$ significant

In a study in 2005 in South Korea on 90 patients with SLE who were compared with 114 controls, it was found that proline carriers had higher risk of developing SLE than those with arginine [21]. However, another study on 513 SLE patients and 567 controls of a Spanish population in 2006 could not find any significant association between codon 72 of p53 polymorphism and lupus as well as its clinical feature [14]. Therefore they concluded that p53 codon 72 polymorphism does not play an important role in the susceptibility to or severity of SLE in their population [14].

Our study showed no significant association between the initial manifestations of SLE as well as laboratory findings and $\mathrm{p53}$. In a study in Poland which was performed on 155 patients and 150 controls, there was no significant association between p53 codon 72 polymorphism and initial symptoms as well as the laboratory findings of lupus but a weak association was reported between Arg/Arg genotype of p53 and lupus morbidity [18]. Our study found a significant association between p53 codon 72 polymorphism and some clinical manifestations of SLE such as photosensitivity, malar rash as well as some morbidities including diarrhea and pulmonary involvement.

A meta-analysis in 2012 that included 6 SLE studies showed that there is a significant association between the p53 C allele and SLE in Asians but not in Europeans [22]. They concluded that p53 codon 72 polymorphism could predict susceptibility to SLE only in Asians, which confirms our results [22].

Differences between findings of various studies may be due to the genetic background and environmental factors that influence disease susceptibility, lupus manifestation and progression.
Having no positive and negative control sample confirmed by sequencing was the main limitation of our study.

In conclusion, according to the results of the present study, it seems that p53 may be a determinant factor in SLE susceptibility and its manifestations and morbidity as well.

\section{Acknowledgment}

We would like to express our sincere gratitude to Farzan Institute for Research \& Technology for technical assistance.

Authors declare no conflict of interests.

\section{References}

1. Zhong S, Huang M, Yang X, et al. Relationship of glutathione S-transferase genotypes with side-effects of pulsed cyclophosphamide therapy in patients with systemic lupus erythematosus. Br J Clin Pharmacol 2006; 62: 457-472.

2. Ruiz-Irastorza G, Khamashta MA, Castellino G. Systemic lupus erythematosus. Lancet 2001; 357: 1027-1032.

3. Rahman A, Isenberg DA. Systemic lupus erythematosus. N Engl J Med 2008; 358: 929-939.

4. D'Cruz DP, Khamashta MA, Hughes GR. Systemic lupus erythematosus. Lancet 2007; 369: 587-596.

5. Lupus Foundation of America. What are the risks for developing lupus. Available at http://www.lupus.org/webmodules/ webarticlesnet/templates/new_learnunderstanding.aspx?articleid=2237\&zoneid=523. Accessed March 22, 2012.

6. Nath SK, Kilpatrick J and Harley JB. Genetics of human systemic lupus erythematosus: the emerging picture. Curr Opin Immunol 2004; 16: 794-800. 
7. Liu CC, Manzi S, Ahearn JM. Biomarkers for systemic lupus erythematosus: a review and perspective. Curr Opin Rheumatol 2005; 17: 543-549.

8. Deng Y, Tsao BP. Genetic susceptibility to systemic lupus erythematosus in the genomic era. Nat Rev Rheumatol 2010; 6: 683-692.

9. Moser KL, Kelly JA, Lessard CJ, et al. Recent insights into the genetic basis of systemic lupus erythematosus. Genes Immun 2009; 10: 373-379.

10. Alarcón-Segovia D, Alarcón-Riquelme ME, Cardiel MH, et al. Familial aggregation of systemic lupus erythematosus, rheumatoid arthritis, and other autoimmune diseases in 1,177 lupus patients from the GLADEL cohort. Arthritis Rheum 2005; 52: 1138-1147

11. Onel KB, Huo D, Hastings D. Lack of Association of the TP53 Arg72Pro SNP and the MDM2 SNP309 with systemic lupus erythematosus in Caucasian, African American, and Asian children and adults. Lupus 2009; 18: 61-66.

12. Bendesky A, Rosales A, Salazar AM, et al. p53 codon 72 polymorphism, DNA damage and repair, and risk of non-melanoma skin cancer. Mutat Res 2007; 619: 38-44.

13. Thomas M, Kalita A, Labrecque S, et al. Two polymorphic variants of wild-type p53 differ biochemically and biologically. Mol Cell Biol 1999; 19: 1092-10100.

14. Sánchez E, Sabio JM, Callejas JL. Study of a functional polymorphism in thep53 gene in systemic lupus erythematosus: lack of replication in a Spanish population. Lupus 2006; 15: 658-661.

15. Madeleine MM, Shera K, Schwartz SM, et al. Cancer Epidemiol. Biomarkers Prev 2000; 9: 225-227.

16. Sreeja L, Syamala V, Raveendran PB, et al. p53 Arg72Pro polymorphism predicts survival outcome in lung cancer patients in Indian population. Cancer Invest 2008; 26: 41-46.

17. Piotrowski P, Lianeri M, Mostowska $M$, et al. Contribution of polymorphism in codon 72 of $\mathrm{p} 53$ gene to systemic lupus erythematosus in Poland. Lupus 2008; 17: 148-151.

18. Buller RE, Sood A, Fullenkamp C, et al. The influence of the p53 codon 72 polymorphism on ovarian carcinogenesis and prognosis. Cancer Gene Ther 1997; 4: 239-245.

19. Chen RH, Chang CT, Wang TY, et al. p53 codon 72 proline/ arginine polymorphism and autoimmune thyroid diseases. J Clin Lab Anal 2008; 22: 321-326.

20. Jin X, Wu X, Roth JA, et al. Higher lung cancer risk for younger African-Americans with the Pro/Pro p53 genotype. Carcinogenesis 1995; 16: 2205-2208.

21. Lee YH, Rho YH, Choi SJ, et al. The functional p53 codon 72 polymorphism is associated with systemic lupus erythematosus. Lupus 2005; 4: 842-845.

22. Lee YH, Bae SC, Choi SJ, et al. Associations between the p53 codon 72 polymorphisms and susceptibility to systemic lupus erythematosus and rheumatoid arthritis: a meta-analysis. Lupus 2012; 21: 430-437. 